\title{
Soil suitability index identifies potential areas for groundwater banking on agricultural lands
}

by A.T. O'Geen, Matthew B.B. Saal, Helen Dahlke, David Doll, Rachel Elkins, Allan Fulton, Graham Fogg, Thomas Harter, Jan W. Hopmans, Chuck Ingels, Franz Niederholzer, Samuel Sandoval Solis, Paul Verdegaal and Mike Walkinshaw

\section{Groundwater pumping chronically exceeds natural recharge in many agricultural} regions in California. A common method of recharging groundwater - when surface water is available - is to deliberately flood an open area, allowing water to percolate into an aquifer. However, open land suitable for this type of recharge is scarce. Flooding agricultural land during fallow or dormant periods has the potential to increase groundwater recharge substantially, but this approach has not been well studied. Using data on soils, topography and crop type, we developed a spatially explicit index of the suitability for groundwater recharge of land in all agricultural regions in California. We identified 3.6 million acres of agricultural land statewide as having Excellent or Good potential for groundwater recharge. The index provides preliminary guidance about the locations where groundwater recharge on agricultural land is likely to be feasible. A variety of institutional, infrastructure and other issues must also be addressed before this practice can be implemented widely.

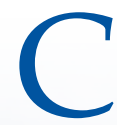
alifornia is experiencing its third major drought since the 1970s, and projections suggest that such episodes will become longer and more frequent in the second half of the 21st century (Barnett et al. 2008; Cayan et al. 2010). Droughts place more demand on groundwater resources to buffer surface water shortfalls. Ordinarily, about $30 \%$ of

Online: http://californiaagriculture.ucanr.edu/ landingpage. $\mathrm{ffm}$ ?article=ca.v069n02p75\&fulltext=yes doi: 10.3733/ca.v069n02p75 the water applied to crops in California (roughly 34 million acre-feet per year) is supplied by groundwater sources, but in times of drought the proportion can increase to as much as 60\% (Megdal 2009). As a result, groundwater levels fall during droughts (Ruud et al. 2004). If groundwater is not replenished during wet years, long-term overdraft occurs. From 2005 through 2010, average annual overdraft in the Central Valley was estimated to be between 1.1 and 2.6 million acre-feet (Department of Water Resources 2015).
Two recent trends in California have tended to increase the rate of groundwater overdraft in agricultural regions.

First, over the past two decades, irrigation technologies have significantly improved water use efficiencies (Canessa et al. 2011; Howell 2001; Orang et al. 2008; Tindula et al. 2013; Ward and PulidoVelazquez 2008). Where surface water is used for irrigation, a consequence of applying less water is that groundwater recharge is diminished because of a reduction in deep percolation of excess water.

Second, expanding worldwide markets have driven significant expansions of nut and wine grape acreage. For example, the almond acreage in California has doubled, to roughly 1 million acres, since 1994 (NASS 2014). Much of this expansion has occurred in the San Joaquin Valley where rates of rainfall and natural groundwater recharge are low. This shift in cropping systems to high value perennial crops reduces the flexibility of agricultural water demand because the economic costs of not irrigating are severe. Inflexible demand has made agriculture even more reliant on groundwater during dry periods when surface water resources are curtailed. 
We modeled each of the five factors using U.S. Department of Agriculture Natural Resources Conservation Service (USDA-NRCS) digital soil survey data. The suitability of each factor was expressed through a scoring system based on a combination of fuzzy logic functions and crisp ratings (see sidebar, this page).

Deep percolation factor. Successful groundwater banking depends on a high rate of water transmission through the soil profile and into the aquifer below. A high percolation rate is especially important if floodwaters are the water source used because floodwaters are available for diversion over a narrow time frame. The deep percolation factor is derived from the saturated hydraulic conductivity $\left(\mathrm{K}_{\text {sat }}\right)$ of the limiting layer (the soil horizon with the lowest $\mathrm{K}_{\text {sat }}$ ). Saturated hydraulic conductivity is a measure of soil permeability when soil is saturated. Many soils in California have horizons (layers) with exceptionally low $\mathrm{K}_{\text {sat }}$ values that severely limit downward percolation, such as cemented layers (duripan, petrocalcic), claypans (abrupt increases in clay content) and strongly contrasting particle size distributions. Soils with these horizons were given crisp scores of 1 . For other soils, a "more is better" fuzzy logic rating curve was applied to a soil profile's lowest $K_{\text {sat }}$ to score the likelihood of deep percolation (fig. 1).

Root zone residence time factor. Prolonged duration of saturated or nearly saturated conditions in the root zone can cause damage to perennial crops, and in some cases, crop loss (table 1). About onethird of California's irrigated cropland is occupied by perennial crops and vines. Table 1 provides estimates of tolerance to saturation for some common tree and vine crops before and after budbreak compiled through a survey of UC ANR Cooperative Extension (UCCE) commodity experts. Annual crops were not included in the survey because we assumed that these fields generally would be fallow during times of excess surface water availability. In general, crops become prone to damage after budbreak and there is a range in tolerance among crops and rootstocks (table 1). For example, wine grapes and pears may be able to withstand more than two weeks of saturated conditions before budbreak, while avocados and citrus have no tolerance.

Our survey identified that many crops are unable to withstand long periods of saturated conditions in the root zone. To account for this potential adverse

TABLE 1. Survey results of tree crop vulnerability to saturated conditions

\begin{tabular}{llccc}
\hline \hline Crop & Rootstock & $\begin{array}{c}\text { Tolerance to saturation } \\
\text { before budbreak }\end{array}$ & $\begin{array}{c}\text { Tolerance to saturation } \\
\text { after budbreak }\end{array}$ & $\begin{array}{c}\text { Recommended N } \\
\text { fertilizer rate }\end{array}$ \\
\hline Almonds & $\begin{array}{l}\text { Peach; peach } x \\
\text { almond hybrid }\end{array}$ & 1 & 1 & lbs N/ac/yr \\
Almonds & $\begin{array}{l}\text { Plum; peach x plum } \\
\text { hybrid }\end{array}$ & $2-3$ & 1 & 250 \\
Avocados & - & & & 250 \\
Cherries & - & 0 & 0 & 150 \\
Citrus & - & 1 & 0 & 60 \\
Wine grapes & - & 0 & 0 & 100 \\
Olives & - & 4 & 2 & $15-30$ \\
Pears & P. betulaefolia & $?$ & $?$ & $<100$ \\
Pears & P. communis & 4 & 4 & $100-150$ \\
Pears & Cydonia oblonga & 4 & 3 & $100-150$ \\
Pistachios & - & $3-4$ & $2-3$ & $100-150$ \\
Plums/prunes & Peach & $?$ & $?$ & 200 \\
Plums/prunes & Plum; peach x plum & 1 & 1 & 150 \\
& hybrid & $2-3$ & 1 & 150 \\
Pomegranate & - & $?$ & $?$ & 100 \\
Walnuts & - & $2-3$ & 1 & 200 \\
\hline
\end{tabular}

The following scores were used to estimate vulnerability: 0 - No tolerance for standing water; 1 - tolerant of standing water up to 48 hours;

2 - tolerant of standing water up to 1 week; 3 - tolerant of standing water up to 2 weeks; 4 - tolerant of standing water $>2$ weeks; ? - tolerance unknown.

Tolerance to saturated conditions is based on expert opinion and has not been supported by controlled experimentation.

outcome, we included in the model a saturation residence time factor for soils. The root zone residence time factor estimates the likelihood of maintaining good drainage within the root zone shortly after water is applied. This rating is based on the harmonic mean of the $\mathrm{K}_{\text {sat }}$ of all horizons in the soil profile, soil drainage class and shrink-swell properties. The harmonic mean is typically used when reporting the average value for rates and tends to be lower than a standard average. Poorly drained soils and soils with high shrinkswell received the lowest scores with a crisp rating of 1 . All other soils were

\section{Fuzzy logic and crisp scores}

F uzzy logic is a method by which membership to a class or condition can be partial (maybe) rather than discrete (true or false; or A or B). Thus, fuzzy logic allows reasoning to be approximate rather than fixed and exact. Variables are evaluated via fuzzy logic scores that range between 1 and 100, reflecting the degree of vagueness of a membership being completely false (1) or completely true (100). Fuzzy logic is appropriate for this model analysis because in agricultural landscapes, the above five factors are relative as opposed to absolute, which poses challenges in quantifying them using the raw data.

We used fuzzy logic statements such as (1) "more is better" where the score increases with higher factor values; (2) "less is better" where the score increases as factor values decrease; and, (3) "optimum range" where the score is highest across a certain range of factor values and decreases above and below that range. Using the suitability of root zone residence time as an example, the fuzzy logic statement "less is better" enables the suitability of that factor to vary between 1 and 100 (from unsuitable to optimally suitable) rather than having to choose between absolutes, e.g., suitable (true) or not suitable (false). Crisp ratings are defined scores that apply to a wellunderstood system, and hence do not require fuzzy scoring. For example, slope classes as reported in soil surveys reflect limitations of common practices such as irrigation and cultivation practices and are scored in our model with crisp ratings. 


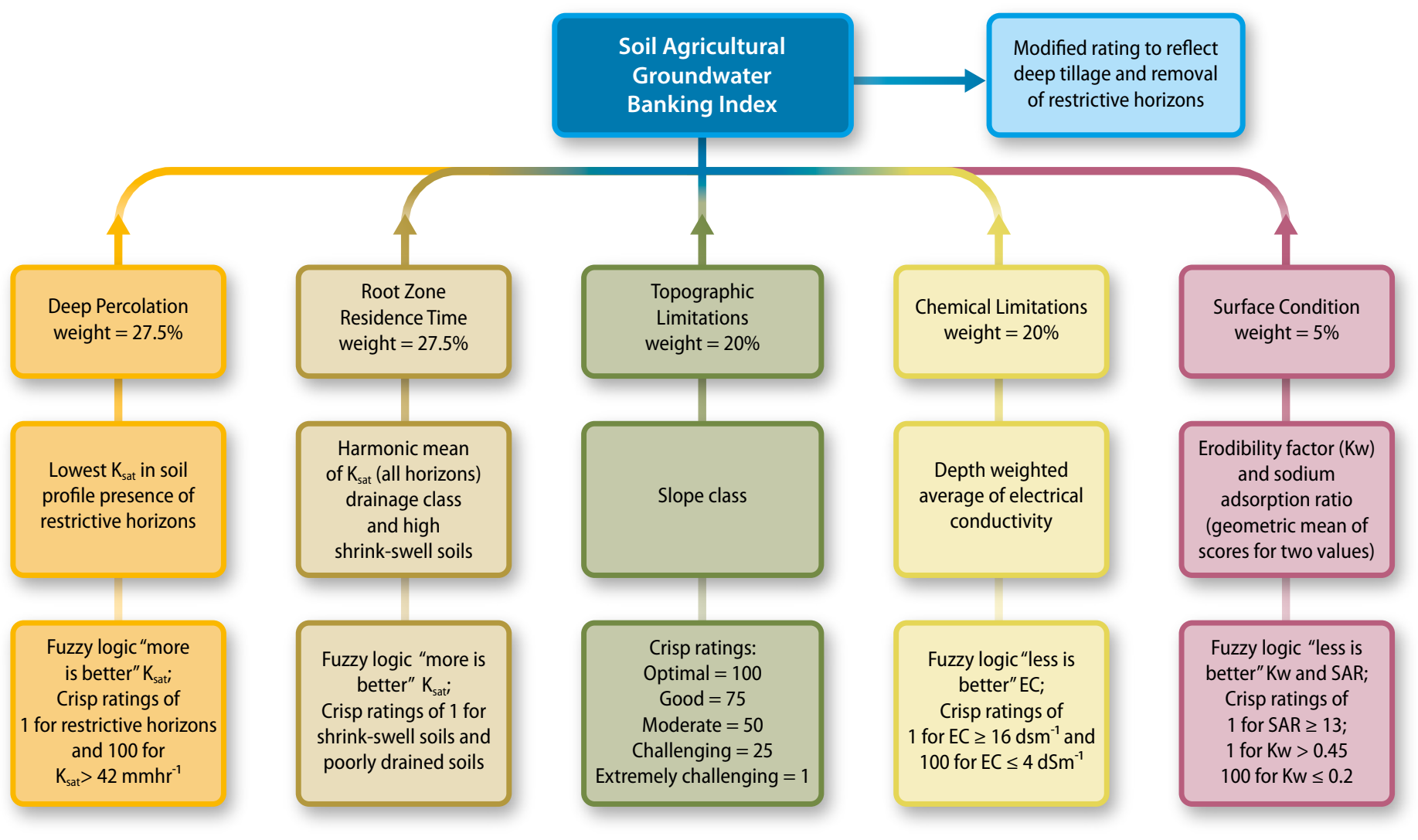

Fig. 1. Schematic of the Soil Agricultural Groundwater Banking Index.

scored using a fuzzy logic rating curve of "more is better" for $\mathrm{K}_{\text {sat }}$ (fig. 1).

Topographic limitations factor.

Agricultural groundwater banking will likely be implemented by spreading water across fields. Level topography is better suited for holding water on the landscape, thereby allowing for infiltration across large areas, reducing ponding and minimizing erosion by runoff. Ranges in slope percent were used to categorize soils into four slope classes: Optimal (slope classes $0 \%-1 \%$ and $0 \%-3 \%$ ), good (slope classes $0 \%-5 \%$ and $2 \%-5 \%$ ), moderate (slope classes $0 \%-8 \%$ and $3 \%-8 \%$ ), challenging (slope classes 5\%-8\%, 3\%-10\% and 5\%$15 \%$ ), and extremely challenging (slope classes $10 \%-30 \%$ and $15 \%-45 \%$ ) (fig. 1 ). Topographic limitations were scored using crisp ratings that generally reflect the USDA-NRCS slope classes because these classes were designed in consideration of limitations for standard agricultural management practices (Soil Survey Division Staff 1993).

Chemical limitations factor. Salinity is a threat to the sustainability of agriculture and groundwater in California, especially along the west side of the Central Valley (Kourakos et al. 2012; Schoups et al. 2005), where sediments are derived from marine sediments in the Coast Range. The chemical limitations factor was quantified using the electrical conductivity (EC) of the soil, which is a measure of soil salinity. A fuzzy logic rating curve "optimum and less is better" was used to score chemical limitations. The "less is better" statement implies that soils with low salinity score high and soils with high salinity values score low. Soil profiles with EC $<4 \mathrm{dS} / \mathrm{m}$ were considered optimal (score of 100). Beyond this threshold, scores decreased with increasing EC. Soils with EC values above $16 \mathrm{dSm}^{-1}$ received a score of 1 (fig. 1). A variety of other contaminants such as pesticides and nitrate are also present in agricultural soils. However, because this type of contamination is dependent on management history, the USDA-NRCS soil survey does not document it and we were unable to evaluate it.

Surface condition factor. Groundwater banking by flood spreading can subject the soil surface to changes in its physical condition. Depending on the quality of the water and depth of water, standing water can lead to the destruction of aggregates, the formation of physical soil crusts and compaction, all of which limit infiltration (Le Bissonais 1996). We used two soil properties to diagnose surface condition, the soil erosion factor and the sodium adsorption ratio (SAR). The surface condition factor was calculated by the geometric mean of fuzzy logic scores from these two properties. A geometric mean is a way to identify the average value of two or more properties that have different ranges in value. SAR values greater than 13 indicate that the soil is prone to crusting. A "less is better" fuzzy logic curve was used to evaluate SAR, where values greater than 13 were assigned a crisp rating of 1 , and values of 0 were assigned an optimal rating of 100 . Soil surface horizon $\mathrm{Kw}$, the soil erodibility factor of the Revised Universal Loss Equation, was used to estimate the potential soil susceptibility to erosion, disaggregation and physical crust formation (USDA-NRCS 2014). A fuzzy logic rating curve, "optimum and less is better," was used for scoring the surface condition factor. $\mathrm{Kw}$ values $<0.20$ were considered ideal (score $=100$ ); beyond this threshold, factor scores decreased with increasing $\mathrm{Kw}$ values.

SAGBI calculation. Each of the five model factor scores was assigned a weight 
based on its significance to groundwater banking (fig. 1). The SAGBI score was calculated by the weighted geometric mean of the scaled factors. The factors were weighted as follows: Deep percolation (27.5\%), root zone residence time (27.5\%), topographic limitations (20\%), chemical limitations (20\%) and surface condition (5\%). Factor weights were applied based on expert opinion. Factors with greater relevance to groundwater recharge were weighted more heavily, while factors that may be modified by management, such as surface condition, were given a lower weight. SAGBI scores were categorized into six groups: Excellent, Good, Moderately Good, Moderately Poor, Poor and Very Poor based on the natural groupings of the dataset.

Soils modified by deep tillage. In recent decades, high value orchard and vineyard crops have expanded onto soil landscapes that contain restrictive horizons. A standard practice for tree and vine establishment on these soils is deep tillage up to a depth of 6 feet to destroy restrictive layers that impede root penetration. This practice increases deep percolation rates and drainage conditions compared to naturally occurring soils. Soils with root- and water-restrictive horizons in California

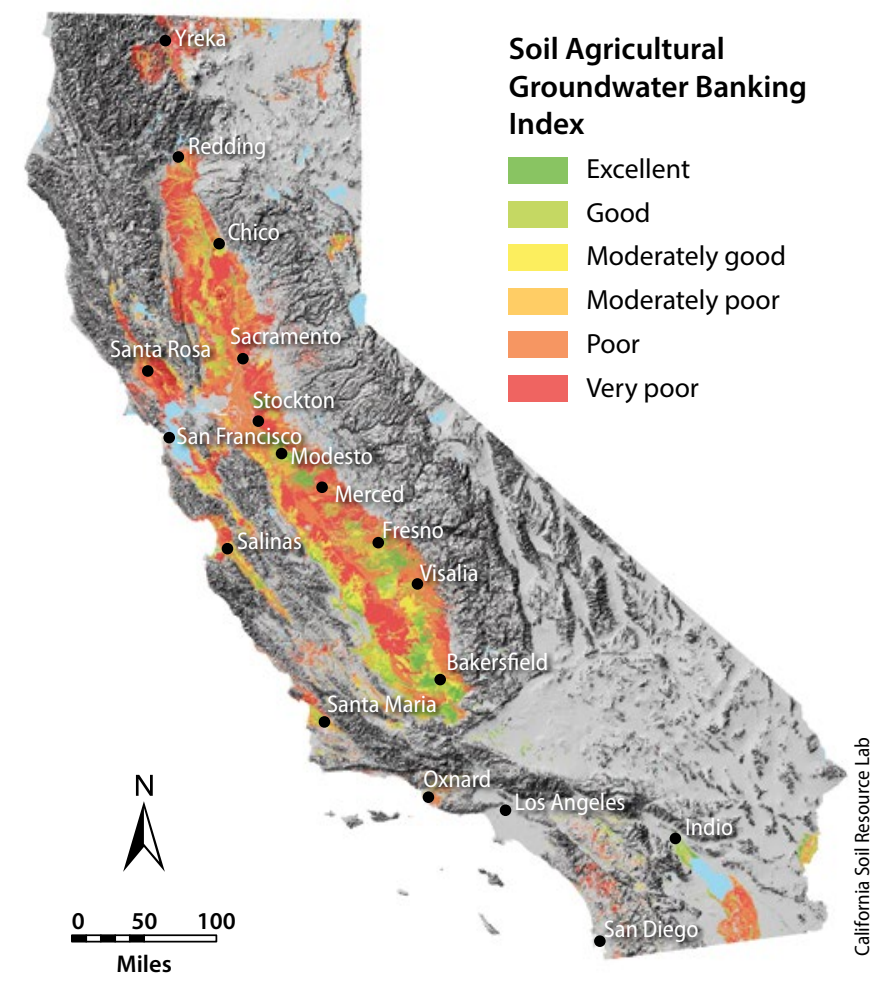

Fig. 2. Spatial extent of Soil Agricultural Groundwater Banking Index suitability groups when not accounting for modifications by deep tillage. have been altered to the point that they are now considered endangered in the Central Valley (Amundson et al. 2003).

As a result, soil surveys of much of the region - many of which were conducted decades ago - are outdated with respect to alterations by deep tillage. To address this problem, we created an updated soil disturbance map using geospatial analysis. A map of orchard and vineyard crops was created using California Department of Water Resources land use maps (issued between 2001 and 2011) and aerial imagery from the National Agricultural Imagery Program (NAIP) and Google Earth (2012 to 2014). This file was overlain in a geographic information system with a map of soils with water-restrictive horizons. We assumed that all tree and vine cropland with restrictive soil layers (based on soil survey data) has been modified by deep tillage, generating an updated map of modified soils.

To reflect the mixing of soil horizons in the calculation of the deep percolation factor, the depth-weighted average of $\mathrm{K}_{\text {sat }}$ for the entire soil profile was used in place of the lowest $\mathrm{K}_{\text {sat }}$ for each profile. We reduced the deep percolation factor rating for soils with claypans by $20 \%$ to reflect the risk that modified claypans

will reform, which can occur in as little as four years in soils with weak structure (White et al. 1981). Cemented layers (not including bedrock) were assumed to have been removed by deep tillage and were not included in the weighted average. Data below the restrictive horizon was included in the depth-weighted average if populated in the database. The depth-weighted average of $\mathrm{K}_{\text {sat }}$ was used in place of the harmonic mean to estimate hydraulic conductivity for the root zone residence time factor.

Map unit aggregation. SAGBI scores were calculated for most agricultural soils populated in the USDA-NRCS Soil Survey Geographic Database (SSURGO). Soil survey delineations represent map units, which often contain more than one soil type. The map units range in size from 5 acres to roughly 500 acres. To create a regional map, each map unit was scored with the SAGBI value using the soil component that comprised the largest percentage of the map unit area. If there was a tie (i.e., one map unit containing two components of equal area), the most limiting (lowest) SAGBI score was chosen for the map unit.

\section{Spatial patterns of SAGBI}

Our study area included over 17.5 million acres of agricultural land (irrigated and non-irrigated) as identified by the state Farmland Mapping and Monitoring Program. Based on our initial modeling, which did not initially consider the effects of deep tillage, soils in the Excellent, Good and Moderately Good suitability groups comprised over 5 million acres, or $28 \%$ of the study area (fig. 2 and table 2 ). These highly rated soils were most abundant on broad alluvial fans on the east side of the Central Valley stemming from the Mokelumne, Stanislaus, Merced, Kern and Kings rivers (fig. 2). Excellent, Good and Moderately Good ratings are also found throughout much of Napa, Salinas and Santa Maria valleys and in patches
TABLE 2. Summary of the areal extent of Soil Agricultural Groundwater Banking Index groups generated from soil survey data

\begin{tabular}{lcccc}
\hline \hline SAGBI group & \multicolumn{3}{c}{$\begin{array}{c}\text { SSURGO modified by } \\
\text { Original SSURGO data }\end{array}$} & \multicolumn{2}{c}{$\begin{array}{c}\text { acres } \\
\text { deep }\end{array}$} & $\%^{*}$ \\
\hline Excellent & acres & 8 & $1,557,035$ & 9 \\
Good & $1,477,191$ & 10 & $2,020,921$ & 11 \\
Moderately Good & $1,747,712$ & 10 & $1,984,414$ & 11 \\
Moderately Poor & $1,786,972$ & 8 & $1,364,066$ & 8 \\
Poor & $1,343,250$ & 28 & $4,586,645$ & 26 \\
Very Poor & $4,866,942$ & 36 & $6,084,142$ & 35 \\
Total† & $6,375,277$ & & $17,597,222$ & \\
\hline
\end{tabular}

* Percent of total study area.

† Modified SAGBI ratings had 123 fewer acres because two soils lacked sufficient data to adjust. 
along the Russian River in Mendocino and Sonoma counties and the northern parts of the Coachella Valley. The best soils - the Excellent and Good groups - occupied about 3.2 million acres, representing $18 \%$ of the study area (fig. 2 and table 2). Some areas of Good and Excellent ratings were found on sandy floodplains of rivers and streams, especially along the Sacramento and Feather rivers.

Floodplains may not be ideal locations for groundwater banking because of the
A.

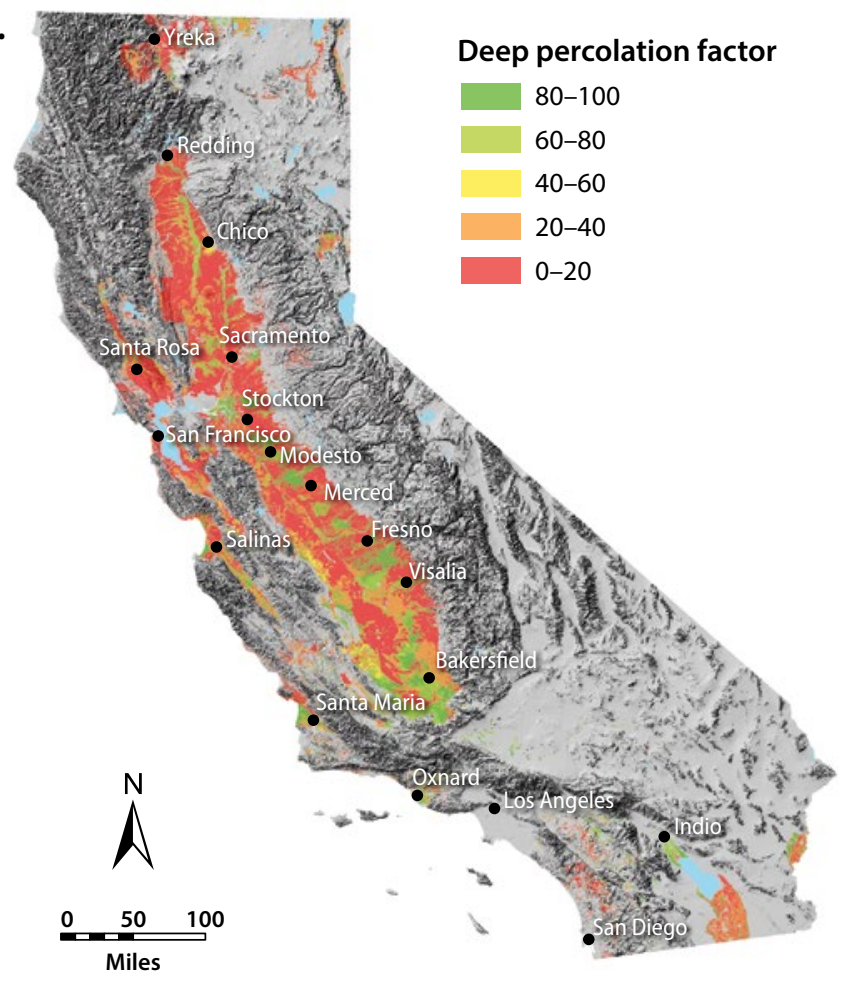

potential for applied water to flow, by subsurface transport, into rivers and streams. Thus, these systems should not be prioritized for groundwater banking unless it is known that the surface water bodies are losing streams - that is, surface water bodies that discharge to groundwater. Most major streams that traverse the San Joaquin Valley, for instance, are known to be losing streams.

Extensive Moderately Good areas were mapped on the western margins of the San Joaquin and Sacramento valleys where soils tend to be finer textured and sometimes salt-affected (saline). Moderately Good groups were also mapped in basin alluvium where low energy flood events have deposited fine sediments. Moderately Good groups occupied $1,786,972$ acres or $10 \%$ of the study area. These areas may require careful consideration for groundwater banking.

The majority of land in the study area (72\% or $~ 12.6$ million acres) was classified as Moderately Poor, Poor or Very Poor SAGBI groups (fig. 2 and table 2). Soils with low SAGBI scores were abundant throughout the basin margins of the Sacramento and San Joaquin valleys as well as across land interstratified between recent alluvial fan deposits of
B.

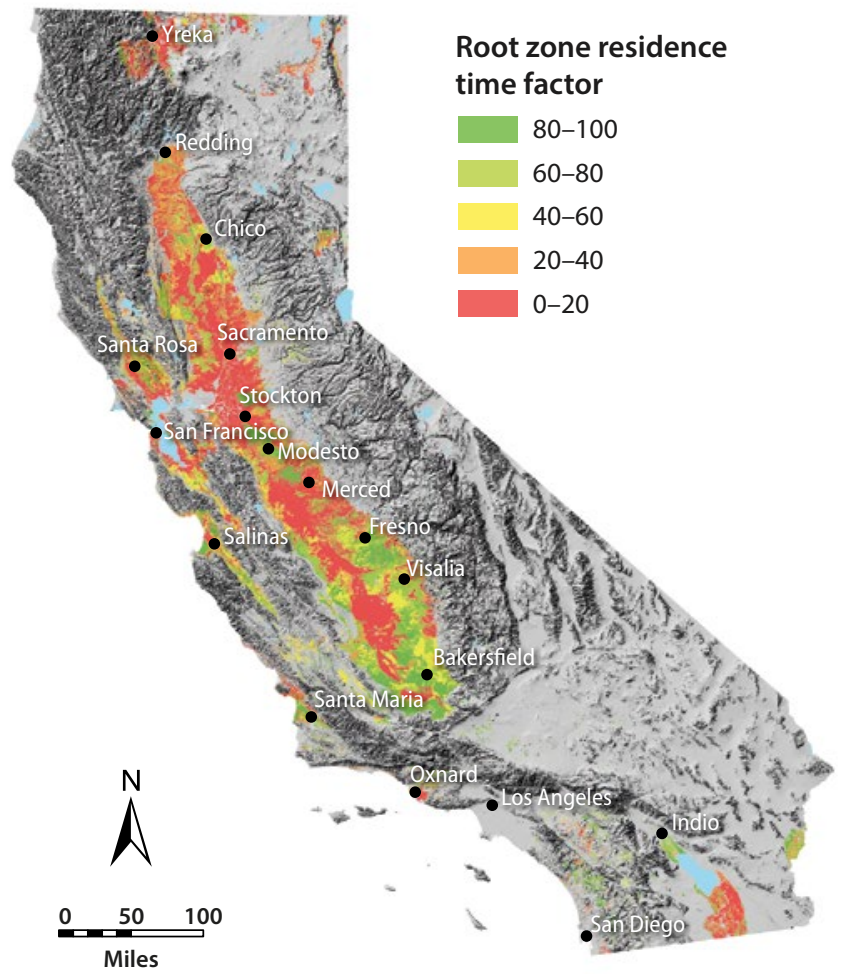

C.

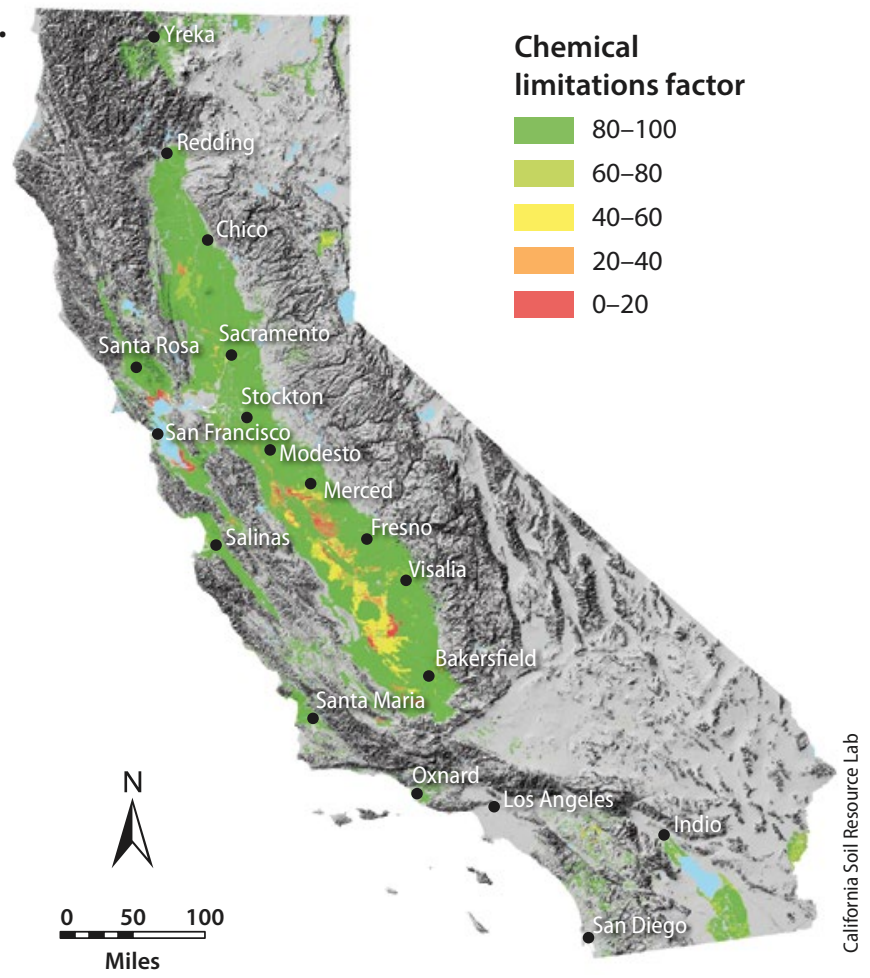

Fig. 3. Spatial extent of Soil Agricultural Groundwater Banking Index factors (A) deep percolation, (B) root zone residence time and (C) chemical limitations. 
the Mokelumne, Tuolumne, Stanislaus, San Joaquin, Kings and Kern rivers. Very Poor and Poor ratings are also found on the northern portions of the Salinas and Santa Maria Valleys and throughout most agricultural regions in Sonoma County and southern parts of the Coachella Valley.

Of the SAGBI components, the deep percolation factor was limiting over the greatest area (fig. 3A). These limiting conditions arise from different characteristics of soils. For example, old, highly developed soils found along the margins of the Central Valley contain water-restrictive horizons (either cemented hardpans or claypans). The center of the valley contains young soils with fine (clay-rich) texture throughout the soil profile. Both of these soil landscapes contain at least one soil horizon with low permeability. In contrast, high deep percolation scores were found on coarse-textured soils derived from recent (e.g., $<80,000$ years) alluvial fans with drainages sourced in granitic terrain of the Sierra Nevada and the Salinian block within the Coast Range.

Areas limited by the root zone residence factor typically had soils with uniformly fine texture throughout the soil profile and poor drainage. Poorly and very poorly drained soils have properties or conditions that promote saturation in the upper parts of the soil profile, such as high clay content, water restrictive layers or regionally shallow water tables. The least suitable soils in this factor were those with poor drainage or high shrinkswell properties. Low scores for root zone residence factor were widespread along the west side of the San Joaquin and Sacramento valleys in soils weathering from Coast Range alluvium (fig. 3B). Poor drainage and fine textured soils were also found in the basin alluvium towards the center of valleys. Low scores for this factor were also found on alluvial fans that have drainages confined to the metamorphic portions of the Sierra Foothills such as the Calaveras River fan, which tend to have fine textured sediments compared to fans sourced in granitic terrain in the high Sierra Nevada.

Chemical limitations had a localized influence on the distribution of SAGBI ratings. Most of the salt-affected soils are present along the west side of the San Joaquin Valley and to a lesser extent along the western margin of the Sacramento Valley (fig. 3C). The distribution of saltaffected soils results from a combination of the salt-rich nature of the marine sediments within the Coast Range and poor drainage conditions on the west side that prevent salts from leaching out of soil. There are other chemical limitations of soils we could not evaluate that would influence groundwater banking, most notably the concentration of residual nitrate in soil. Crops with high nitrogen demand or high residual nitrate in soil in the fall after harvest may not be suitable for groundwater banking (table 1).

The surface condition factor was weighted lowest among all other factors because compaction from standing water can be fixed with tillage and amendments. Low surface condition factor ratings were abundant in soils with loamy surface textures or high SAR and were located throughout the study area but tended to be concentrated on the west side of the Central Valley where sodiumaffected soils are common (fig. 4A).

Soil landscapes with low slope factor ratings were limited to the margins of the valleys (fig. 4B). This sloping terrain is a result of uplift by the Coast Range and Sierra Nevada over geologic time scales, which increased slope gradients and accelerated erosion. The natural erosion of the valley margins has created gentle to
A.

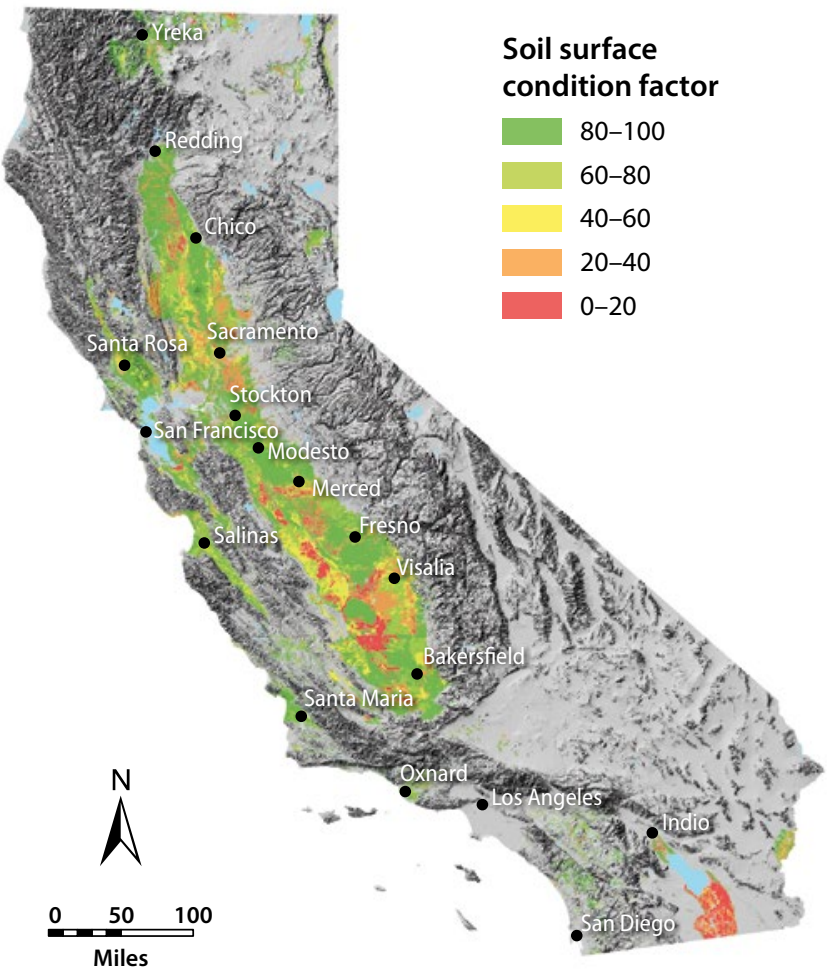

B.

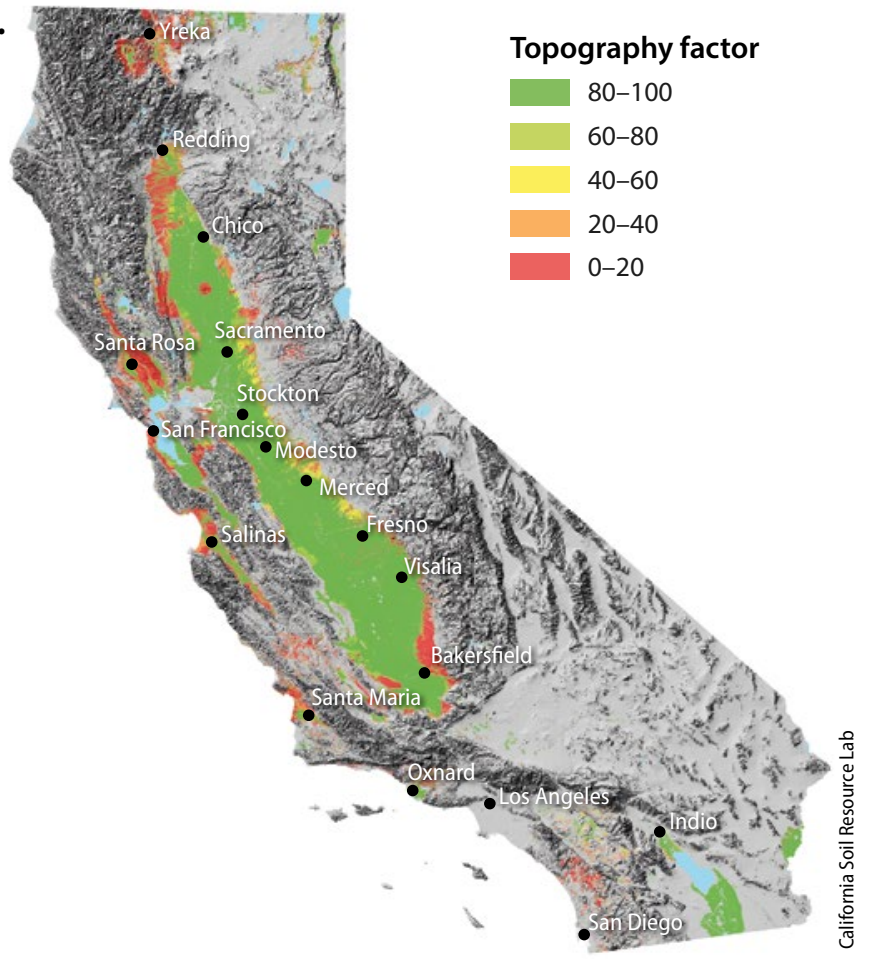

Fig. 4. Spatial extent of Soil Agricultural Groundwater Banking Index factors (A) surface condition and (B) topographic limitations. 
estimate assumes 1 foot per day of water infiltration on lands in the Excellent and Good categories that are planted with grapes $(460,000$ acres) or alfalfa $(300,000$ acres), or fallowed (440,000 acres). There are significant limitations to this estimate. Most importantly, California lacks the infrastructure to accommodate and route such large volumes of water to the fields in such a short time (presuming that floodwater is the source of the water). Plus, the heterogeneity in precipitation across the state makes this estimate improbable (that is, it is unlikely that floodwater availability would be geographically close to the best lands for recharge). Offsetting these limitations to some degree are other crop types that would be suitable for recharge (i.e., annual crops) but were not included in this estimate.

Agricultural groundwater banking must be approached with caution. The financial risk associated with crop loss may exceed the potential benefits of water savings. Perennial crops carry particular risks and uncertainties. For instance, while trees and vines are generally more tolerant of saturation before budbreak than after (table 1), determining a reliable cutoff date for this increased tolerance is difficult. Tree and vine roots generally start to grow several weeks before budbreak, so damage from waterlogging can occur well before budbreak. Moreover, budbreak for a given species varies by location across the state. In addition, standing water on trunks can lead to aerial Phytophthora or other diseases. Investigating this opportunity in less valuable cropping systems, such as alfalfa, irrigated pasture and annual crops may be more promising until further research on tree crop sensitivity to standing water has been conducted.

If groundwater banking on agricultural lands becomes a priority, coordination at the policy, market and planning levels would be needed to provide an adequate land base ready to opportunistically capture floodwaters. Adoption of this practice would likely require some form of support to mitigate or protect growers from the risks of crop failure. For example, growers who make their land available for floodwater capture and groundwater banking could receive credits from municipalities or irrigation districts. They could also receive credits from
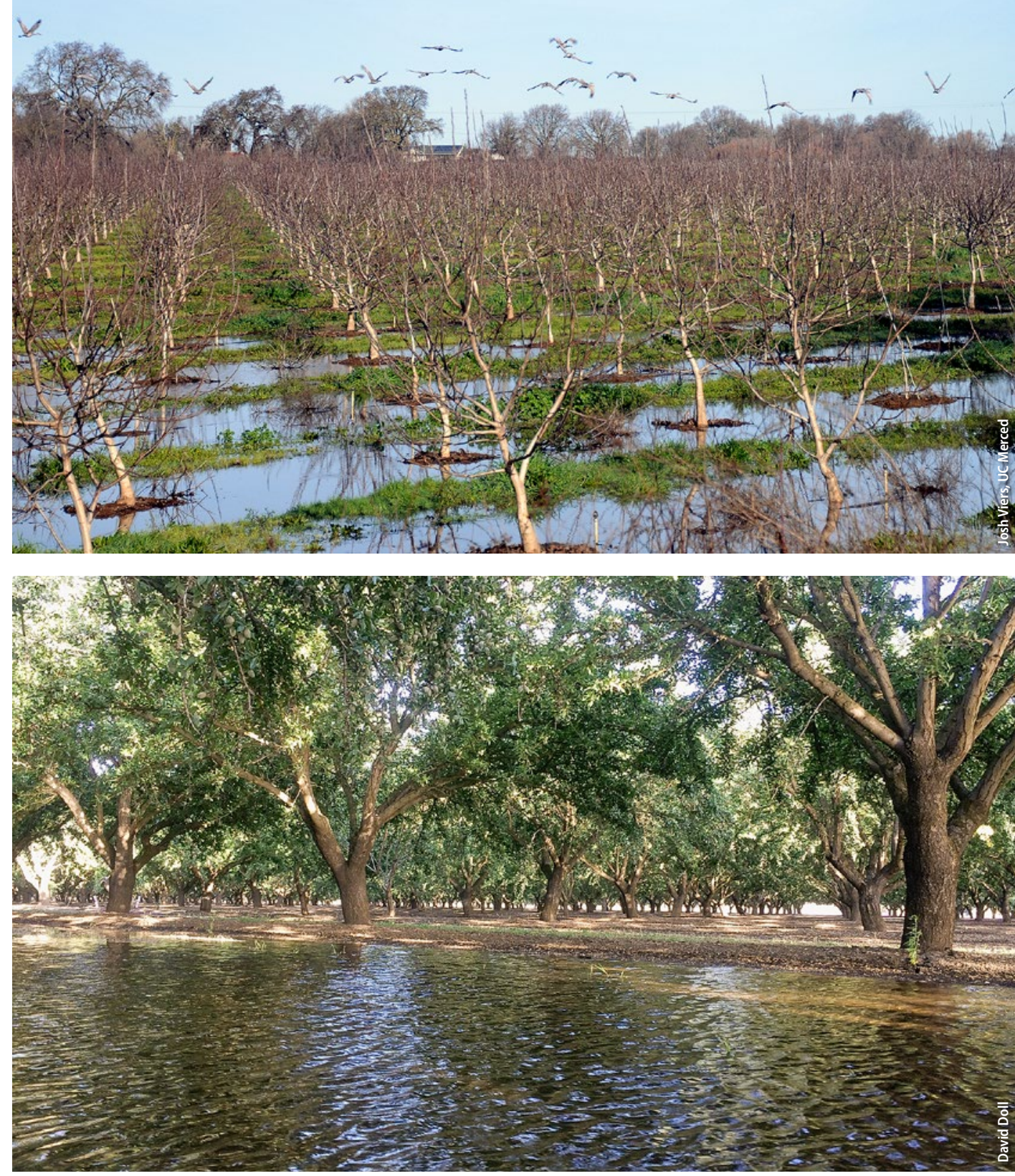

Orchards of walnuts (above) and almonds (below) may be viable sites for groundwater recharge, though the potential for water damage to such high-value crops adds risk.

irrigation districts for enrolling in a longterm program. Long-term commitments from growers likely would be needed for basin-scale planning purposes.

Although not included among the crops listed in table 1, alfalfa may be an ideal crop for groundwater banking because it requires little or no nitrogen fertilizer, reducing the risk that groundwater recharge would transport nitrates into aquifers. Alfalfa is sensitive to flooding and saturated conditions; thus the timing of flooding should coincide with older fields (typically 4 to 5 years old) slated for replanting. Because the financial risk associated with crop damage is lower in alfalfa than in tree and vine crops, the financial incentive needed to drive grower participation in groundwater banking programs likely would be lower as well.

Most annual cropping systems would be suitable for groundwater banking if water is applied when land is fallow. The major risk in annual crops is leaching of residual pesticides or fertilizer in the soil. Appropriate management practices for groundwater banking with specific annual crops would need to be developed. If agricultural groundwater banking becomes an important water security practice, the SAGBI may provide valuable information to guide future changes in cropping systems.

SAGBI can be a powerful aid to decision makers and stakeholders when considering the tradeoffs associated with the 
implementation of groundwater banks utilizing agricultural land for direct recharge. It was also developed with the intention of informing growers of the potential hazards associated with this practice. As is the case with any model, and with soil survey information in particular, ground-truthing at the field scale is necessary to verify results. during groundwater banking events. Furthermore, deep sediment likely contains hydraulically restrictive horizons that have not been documented, creating uncertainty as to where the water travels. An understanding of the depth to the groundwater table is also needed.

Given these issues, SAGBI may be most useful when used in concert with water

\section{If agricultural groundwater banking becomes an important water security practice, the SAGBI may provide valuable information to guide future changes in cropping systems.}

We acknowledge limitations to our model. It does not consider proximity to a surface water source, which is an issue especially in areas that are irrigated solely from groundwater wells and are not connected to conveyance systems that supply surface water. The SAGBI also does not consider characteristics of the vadose zone (the unconsolidated material below soil and above the groundwater table) or depth to groundwater. In arid regions, deep vadose zones may contain contaminants such as salts or agricultural pollutants that have accumulated over years of irrigation and incomplete leaching. These deep accumulations of contaminants could be flushed into the water table when excess water is applied infrastructure models and hydrogeologic models - which generally do not incorporate soil survey information in a comprehensive way - to develop a fuller assessment of the processes and limitations involved in a potential groundwater banking effort.

\section{Information delivery}

Our goal is to make SAGBI an interactive, web-based app. The decision support tool will display SAGBI groups as a map in Google Maps. Users will be able to navigate via standard map interface operations such as zoom tools and panning, or by entering a location in a search field to obtain SAGBI ratings. Users will also be able to query and display the individual ratings of each SAGBI factor for any location that has a SAGBI rating, illustrating the transparency of the model and allowing for further investigation of individual factors. CA

\section{A.T. O'Geen is UC Agriculture and Natural Resources} Cooperative Extension (UCCE) Specialist; M.B.B. Saal is Graduate Student in the Soils and Biogeochemistry Graduate Group at UC Davis; H. Dahlke is Assistant Professor in the Department of Land, Air and Water Resources at UC Davis; D. Doll is UCCE Farm Advisor in Merced County; R. Elkins is UCCE Farm Advisor in Lake and Mendocino counties; A. Fulton is UCCE Irrigation and Water Resources Advisor in Tehama County; G. Fogg is Professor, T. Harter is UCCE Specialist, and J.W. Hopmans is Associate Vice Provost and Professor in the Department of Land, Air and Water Resources at UC Davis; C. Ingels is UCCE Farm Advisor in Sacramento County; F. Niederholzer is UCCE Farm Advisor in SutterYuba counties; S. Sandoval Solis is Assistant Professor and UCCE Specialist in the Department of Land, Air and Water Resources at UC Davis; P. Verdegaal is UCCE Farm Advisor in San Joaquin County; and M. Walkinshaw is GIS Analyst in the Department of Land, Air and Water Resources at UC Davis.

This research was conducted with funding from the UC ANR Competitive Grants Program. We also thank the anonymous reviewers for their helpful feedback.

\section{References}

Amundson R, Guo Y, Gong P. 2003. Soil diversity and land use in the United States. Ecosystems 6:470-82.

Barnett TP, Pierce DW, Hidalgo HG, et al. 2008. Human-induced changes in the hydrology of the western United States. Science 316:1080-83.

Bachand PAM, Horwath WR, Roy SB, et al. 2011. On-farm flood flow capture - Addressing flood risks and groundwater overdraft in the Kings Basin, with potential applications throughout the Central Valley. Davis, CA: Bachand \& Associates. 4 p. http://aquaticcommons.org/11289/ (accessed May 2015).

Canessa P, Green S, Zoldoske D. 2011. Agricultural Water Use in California: A 2011 Update. Center for Irrigation Technology, Fresno State University, November. www. californiawater.org/cwi/docs/CIT_AWU_REPORT_v2.pdf. Cayan DR, Das T, Pierce DW, et al. 2010. Hydrology of the early 21 st century Southwest drought: Possible harbinger of future decades. P Natl Acad Sci USA 107:21271-76.

Charbonneau R, Kondolf GM. 1993. Land use change in California: Nonpoint source water quality impacts. Environ Manage 17:453-60.

Department of Water Resources. 2015. California's Groundwater Update 2013. A Compilation of Enhanced Content for California Water Plan Update 2013. State of California Natural Resources Agency. April 2015. www. waterplan.water.ca.gov/docs/groundwater/update2013/ content/statewide/GWU2013_Combined_Statewide_Final.pdf.
Howell TA. 2001. Enhancing water use efficiency in irrigated agriculture. Agron J 93:281-9. doi:10.2134/ agronj2001.932281x

Kourakos G, Klein F, Cortis A, Harter T. 2012. A groundwater nonpoint source pollution modeling framework to evaluate lon-term dynamics of pollutant exceedance probabilities in wells and other discharge locations. Water Resour Res 48: WO0L13. doi:10.1029/2011WR010813.

Le Bissonnais Y. 1996. Aggregate stability and assessment of soil crustability and erodibility: I. Theory and methodology. Eur J Soil Sci 47:425-37.

Megdal S, Hamann R, Harter T, et al. 2009. Water, People, and the Future: Water Availability for Agriculture in the United States. CAST Issue Paper 44. 20 p.

[NASS] National Agricultural Statistics Service. 2014. National Agricultural Statistics Service website. www.nass. usda.gov/.

Orang M, Matyac SJ, Snyder R. 2008. Survey of irrigation methods in California in 2001. J Irrig Drain Eng 134:96-100

Ruud N, Harter T, Naugle A. 2004. Estimation of groundwater pumping as closure to the water balance of a semi-arid, irrigated agricultural basin. J Hydrol 297:51-73. Schoups G, Hopmans JW, Young CA, et al. 2005. Sustainability of irrigated agriculture in the San Joaquin Valley, California. P Natl Acad Sci USA 102:15352-6.
Soil Survey Division Staff. 1993. Soil survey manual. Soil Conservation Service. US Department of Agriculture Handbook 18.

Tindula G, Orang M, Snyder R. 2013. Survey of irrigation methods in California in 2010. J Irrig Drain Eng: 139:233-8.

USDA-NRCS. 2014. California Soil Survey Status Map. www.nrcs.usda.gov/Internet/FSE_DOCUMENTS/ nrcs144p2_063838.pdf (accessed October 2014). Ward FA, Pulido-Velazquez M. 2008. Water conservation in irrigation can increase water use. P Natl Acad Sci USA 105:18215-20. doi:10.1073/pnas.0805554105.

Water Association of Kern County. 2014. Water banking. www.wakc.com/index.php/water-overview/sources-ofwater/87-water-banking (accessed October 2014). White EM, Gartner FR, Butterfield R. 1981. Range claypan soil improvement: response from furrowing and ripping in northwestern South Dakota. J Range Manage 34:119-25. 